\title{
The importance of platelet counts in severe hypothermia
}

Ian Joseph Cohen ${ }^{1,2,3}$ (D)

Keywords: Hypothermia thrombocytopenia, Rewarming deaths

To the editor,

I would like to congratulate Bunya et al. for their case report of a successful recovery of a patient after severe hypothermia published recently in the journal [1]. It is rewarding to see that their dedication and refusal to assume that the patient was dead resulted in successful recovery. I would like to comment on what may seem to be a minor detail in the report but would seem to me to be very significant. The authors report that the platelet count on admission was $14.7 \times 104 / \mu \mathrm{l}$, i.e., $147,000 / \mathrm{mm}^{3}$. This is a very unusual finding in severe hypothermia since thrombocytopenia is to be expected in this condition (especially in a patient with a core temperature as low as $22{ }^{\circ} \mathrm{C}$ ) and is the basis of the bleeding complications that may be responsible for "rewarming deaths." We have described this in infants who have become hypothermic and have shown that the thrombocytopenia becomes much more marked on rewarming due to priming of the platelets by the cold $[2,3]$. We have shown (in blood from adults) that below $30{ }^{\circ} \mathrm{C}$ the second phase of platelet aggregation and release of dense granules is blocked but that rewarming causes massive activation of platelets.

Aspirin has been shown to prevent these rewarming changes [4], and other compounds have been shown to affect platelet function in a similar way. A possible explanation for the lack of thrombocytopenia in this case is the "premedication" the patient took with sleeping tablets [5] and alcohol [6] both of which may well have prevented both the thrombocytopenia and also the deepening of the platelet count on rewarming and thus avoided this potentially fatal complication during

Correspondence: icohen@tau.ac.il

${ }^{1}$ Sackler Faculty of Medicine, Tel Aviv University, Ramat Aviv, Israel

${ }^{2}$ The Rina Zaizov Hematology-Oncology Division, Schneider Children's

Medical Center of Israel, Petach Tikva, Israel

Full list of author information is available at the end of the article recovery. It is important that the treating physicians of other patients without such "premedication" are aware of the importance of following the platelet counts especially as the patients are being rewarmed, since giving platelets at that stage has been shown to prevent any bleeding complications [2] and a lack of awareness of the importance of thrombocytopenia may result in unexplained mortality.

\section{Acknowledgements}

None.

Author's contributions

Everything was done by Prof IJC. The author read and approved the final manuscript.

\section{Funding}

No funding was received.

Availability of data and materials

Data sharing is not applicable to this article as no datasets were generated or analyzed during the current study.

Ethics approval and consent to participate

Not required (no studies involving human participants, human data, or human tissue)

\section{Consent for publication}

Not required (contains no individual person's data in any form (including individual details, images, or videos))

\section{Competing interests}

The author declares that he has no competing interests.

\section{Author details}

${ }^{1}$ Sackler Faculty of Medicine, Tel Aviv University, Ramat Aviv, Israel. ${ }^{2}$ The Rina Zaizov Hematology-Oncology Division, Schneider Children's Medical Center of Israel, Petach Tikva, Israel. ${ }^{3} 139$ Shir Hashirim St, 44814 Elkanah, Israel.

Received: 4 December 2018 Accepted: 17 July 2019

Published online: 23 July 2019

\section{References}

1. Bunya N, Sawamoto K, Kakizaki R, Wada K, Katayama Y, Mizuno H, et al. Successful resuscitation for cardiac arrest due to severe accidental hypothermia accompanied by mandibular rigidity: a case of cold stiffening mimicking rigor mortis. Int J of Emerg Med. 2018;11:46-9. 
2. Cohen IJ, Amir J, Gedaliah A, Rachmal A, Gorodischer R, Zaizov R. Thrombocytopenia of neonatal cold injury. The J of Ped. 1984;104:620-2.

3. Cohen IJ. Room temperature ADP -induced first stage hyperaggregation of human platelets :the cause of rewarming deaths by thrombocytopenia in neonatal cold injury. Ped Hematol and Oncol. 1991;8:61-7.

4. Cohen IJ, Fuchs J, Kaplinski C, Krugliak J, Stark B, Vogel R, et al. Room temperature ADP induced first stage hyperaggregation of human blood platelets:a previously undescribed phenomenom and its relationship to spontaneous cold induced platelet aggregation. B J Haematol. 1987;65: 331-4 errata notice 1987;67:121.

5. Romstedt K, Aakbar H. Benzodiazepines inhibit human platelet activation: comparison of the mechanism of antiplatelet actions of flurazepam and diazepam. Thromb Res. 1985;38:361-74.

6. Renaud SC, Ruf JC. Effect of alcohol on platelet function. Clin Chimica Acta. 1996:264:77-89.

\section{Publisher's Note}

Springer Nature remains neutral with regard to jurisdictional claims in published maps and institutional affiliations.

Ready to submit your research? Choose BMC and benefit from:

- fast, convenient online submission

- thorough peer review by experienced researchers in your field

- rapid publication on acceptance

- support for research data, including large and complex data types

- gold Open Access which fosters wider collaboration and increased citations

- maximum visibility for your research: over $100 \mathrm{M}$ website views per year

At BMC, research is always in progress.

Learn more biomedcentral.com/submissions 